\title{
Liquid culture production of microsclerotia and submerged conidia by Trichoderma harzianum active against damping-off disease caused by Rhizoctonia solani ${ }^{\text {ts }}$
}

\author{
Nilce N. KOBORI ${ }^{a}$, Gabriel M. MASCARIN ${ }^{a, b, *}$, Mark A. JACKSON ${ }^{a}$, \\ David A. SCHISLER ${ }^{a}$ \\ ${ }^{a}$ United States Department of Agriculture, Agriculture Research Service, Crop Bioprotection Research Unit, National \\ Center for Agricultural Utilization Research, 1815 N. University St., Peoria, IL 61604, USA \\ ${ }^{\mathrm{b}}$ Embrapa Rice and Beans, Rodovia GO-462, Km 12, Zona Rual, C.P. 179, 75375-000, Santo Antônio de Goiás, \\ GO 75375-000, Brazil
}

\section{A R T I C L E I N F O}

Article history:

Received 6 September 2014

Received in revised form

26 November 2014

Accepted 10 December 2014

Available online 19 December 2014

Corresponding Editor:

Nicholas Money

Keywords:

Biofungicide

C:N ratio

Desiccation tolerance

Sclerotia

Soilborne disease

Storage stability

\begin{abstract}
A B S T R A C T
Media and culturing protocols were identified that supported the formation of submerged conidia and microsclerotia (MS) by Trichoderma harzianum Rifai strain T-22 using liquid culture fermentation. Liquid media with a higher carbon concentration $\left(36 \mathrm{~g} \mathrm{~L}^{-1}\right)$ promoted MS formation at all C:N ratios tested. Hyphae aggregated to form MS after $2 \mathrm{~d}$ growth and after $7 \mathrm{~d}$ MS were fully melanized. This is the first report of MS formation by T. harzianum or any species of Trichoderma. Furthermore, submerged conidia formation was induced by liquid culture media, but yields, desiccation tolerance, and storage stability varied with C:N ratio and carbon rate. Air-dried MS granules ( $<4 \%$ moisture) retained excellent shelf life under cool and unrefrigerated storage conditions with no loss in conidial production. A low-cost complex nitrogen source based on cottonseed flour effectively supported high MS yields. Amending potting mix with dried MS formulations reduced or eliminated damping-off of melon seedlings caused by Rhizoctonia solani. Together, the results provide insights into the liquid culture production, stabilization process, and bioefficacy of the hitherto unreported MS of T. harzianum as a potential biofungicide for use in integrated management programs against soilborne diseases.
\end{abstract}

(c) 2014 The British Mycological Society. Published by Elsevier Ltd. All rights reserved.

\section{Introduction}

Biological control agents are gaining more attention in recent years owing to their potential to minimize or replace synthetic chemical pesticides in main-stream agriculture. The genus Trichoderma is a well-known, cosmopolitan soil fungus that has been widely explored as an antagonist of numerous plant pathogenic fungi in agriculture (Howell

\footnotetext{
is "Mention of trade names or commercial products in this article is solely for the purpose of providing specific information and does not imply recommendation or endorsement by Embrapa or by USDA."

* Corresponding author. Tel.: +55 623533 2169; fax: +55 6235332100.

E-mail addresses: nnaomik@yahoo.com.br (N. N. Kobori), gabriel.mascarin@embrapa.br, gmmascar@gmail.com (G. M. Mascarin), mark.jackson@ars.usda.gov (M. A. Jackson), david.schisler@ars.usda.gov (D. A. Schisler). http://dx.doi.org/10.1016/j.funbio.2014.12.005

1878-6146/@ 2014 The British Mycological Society. Published by Elsevier Ltd. All rights reserved.
} 
2003; Harman 2006). Isolates of Trichoderma species can be successful in plant disease control due to directly antagonizing pathogen activity and/or inducing host resistance responses (Harman 2000). Furthermore, Trichoderma's function as a plant growth promoter has been reported for some strains after establishment as a non-strict plant symbiont by colonizing the rhizosphere (Harman \& Kubicek 1998; Harman 2000; Harman et al. 2004). Multitude modes of action for Trichoderma strains employed as biocontrol agents are claimed to be: a) rhizosphere competence by colonizing the soil and/or parts of the plant or by competition for nutrients; b) mycoparasitism by producing a wide variety of cell wall degrading enzymes against pathogens; c) antibiosis via production of antimicrobial compounds (volatiles and non-volatiles) that can kill the pathogens; d) growth promotion by improving plant development, and e) induction of systemic defensive responses in plants (Harman \& Kubicek 1998; Howell 2003; Harman 2006).

The majority of Trichoderma-based biopesticides consists primarily on aerial conidia that are produced using solid substrate fermentation on moistened grains (Bettiol 2011; Woo et al. 2014). This process takes weeks for production and drying, which increases production costs (Pandey et al. 2008; Ramanujam et al. 2010). The production of fungal conidia on moistened grains suffers from numerous constraints including high labour costs, poor quality control, long fermentation times, environmental concerns for workers, and difficulties in scale-up. Liquid culture production methods have been investigated and focused on the production of submerged conidia and chlamydospores of Trichoderma (Lewis \& Papavizas 1983; Papavizas et al. 1984; Tabachnik 1989; Harman et al. 1991; Jin et al. 1996; Sriram et al. 2011). Although liquid fermentation technology has been adopted by some biopesticide companies around the globe for production of submerged conidia, no reports on yields, fermentation time, production costs, and comparison with aerial conidia in terms of bioefficacy are provided. Formulation studies have focused on stabilization processes for Trichoderma biomass, aerial conidia, and chlamydospores that provided adequate storage stability and bioefficacy (Lewis \& Papavizas 1985; Jin \& Custis 2010; Yonsel \& Batum 2010; Sriram et al. 2011). Despite these attempts to produce Trichoderma in liquid culture, low yields, long fermentation times, and poor desiccation tolerance and storage stability have impaired the large-scale adoption of this production methodology by industry.

Commercially, Trichoderma harzianum Rifai strain T-22 is one of the most used active ingredients for biocontrol of root diseases in the USA (Woo et al. 2014). In 2011, there were five registered commercial products based on Trichoderma-aerial conidia in Brazil with several multinational companies working on developing Trichoderma products that are currently applied to more than 3 million ha per year (Bettiol 2011). To meet the biopesticide market expectations and promote Trichoderma's widespread use in agriculture, an efficient liquid culture production technology must be developed that yields a high quality Trichoderma-based product.

Liquid fermentation technology has the potential to support high yields of stable, effective Trichoderma propagules produced under rigorous control quality and ensuring a consistent and uniform product. Although submerged conidia, mycelia, and chlamydospores of $\mathrm{T}$. harzianum can be produced using liquid fermentation, these fungal forms are often produced in low yield, lack storage stability, or persist poorly in soil. While previous studies with other biocontrol fungi have shown that microsclerotia (MS) of Colletotrichum truncatum, Mycoleptodiscus terrestris, and Metarhizium brunneum could be rapidly produced in liquid culture, there are no reports of sclerotia formation in the genus Trichoderma (Jackson \& Schisler 1995; Shearer \& Jackson 2006; Jackson \& Jaronski 2009, 2012; Behle \& Jackson 2014). Fungal MS are preferable propagules for application in soil since they are overwintering, resistant fungal structures with the intrinsic ability to survive stress conditions, such as desiccation and soil fungistasis (i.e., competition with other soil microorganisms).

In the present study, we assessed the impact of various nutritional environments on the filamentous growth and morphogenetic differentiation of cultures of $\mathrm{T}$. harzianum. Using baffled flasks, cultures of $\mathrm{T}$. harzianum were grown in liquid media containing various carbon concentrations, carbon-to-nitrogen ratios, and nitrogen sources with measurements of biomass accumulation, propagule formation, and propagule yield during culturing. Propagules of T. harzianum produced under these various culture conditions included submerged conidia and MS. Submerged conidia and MS were air-dried to evaluate desiccation tolerance and stored as dry formulations to assess storage stability. Bioassays were conducted with air-dried MS against damping off disease in melon incited by Rhizoctonia solani.

\section{Materials and methods}

\section{Culture maintenance}

Trichoderma harzianum Rifai strain T-22 (ATCC 20847; Rootshield $^{\circledR}$, BioWorks, Geneva, NY) was used throughout this study. Pure cultures of T. harzianum were isolated from serial dilutions of Rootshield ${ }^{\circledR}$ and grown on potato dextrose agar (PDA, Difco ${ }^{\circledR}$ ) at $25 \pm 1{ }^{\circ} \mathrm{C}$ for at least $7 \mathrm{~d}$. Single colonies were purified by re-isolation on PDA and a single hyphal tip was isolated and grown on PDA. The sporulated colony arising from this hyphal tip was used as a stock culture of T. harzianum T-22 and was cut into $1 \mathrm{~mm}^{2}$ pieces, placed in cryovials containing $1 \mathrm{~mL}$ of a sterile solution of $10 \%(\mathrm{v} / \mathrm{v})$ glycerol (Fisher Scientific, Pittsburgh, PA, USA) prepared with double deionized water, and stored at $-80^{\circ} \mathrm{C}$.

For liquid culture studies, conidial inocula were obtained by inoculating PDA plates with a conidial suspension from the frozen stock cultures and growing the cultures at $25 \pm 1{ }^{\circ} \mathrm{C}$ for $2-3$ weeks. Conidial suspensions were obtained from sporulated agar plates by rinsing plates with $10 \mathrm{~mL}$ of a sterile solution containing $0.04 \%$ polyoxyethylene sorbitan mono-oleate (Tween 80, Sigma ${ }^{\circledR}$ ).

\section{Shake-flask culturing and media evaluation}

Growth and propagule formation by Trichoderma harzianum was assessed in liquid media containing different carbon concentrations, carbon-to-nitrogen $(\mathrm{C}: \mathrm{N})$ ratios, and nitrogen sources using a semi-defined liquid medium composed of 
basal salts with glucose $\left(\operatorname{Sigma}{ }^{\circledR}\right)$ and acid hydrolyzed casein (Casamino Acids ${ }^{\circledR}$, Difco Laboratories, Detroit, MI, USA) as the carbon and nitrogen sources, respectively. The defined basal salts medium used in all growth studies contained per liter: $\mathrm{KH}_{2} \mathrm{PO}_{4}, 2.0 \mathrm{~g} ; \mathrm{CaCl}_{2} \cdot 2 \mathrm{H}_{2} \mathrm{O}, 0.4 \mathrm{~g} ; \mathrm{MgSO}_{4} \cdot 7 \mathrm{H}_{2} \mathrm{O}$, $0.3 \mathrm{~g} ; \mathrm{FeSO}_{4} \cdot 7 \mathrm{H}_{2} \mathrm{O}, 0.05 \mathrm{~g} ; \mathrm{CoCl}_{2} \cdot 6 \mathrm{H}_{2} \mathrm{O}, 37 \mathrm{mg} ; \mathrm{MnSO}_{4} \cdot \mathrm{H}_{2} \mathrm{O}$, $16 \mathrm{mg} ; \mathrm{ZnSO}_{4} \cdot 7 \mathrm{H}_{2} \mathrm{O}, 14 \mathrm{mg}$; thiamin, riboflavin, pantothenate, niacin, pyridoxamine, thioctic acid, $500 \mu \mathrm{g}$ each; and folic acid, biotin, vitamin $B_{12}, 50 \mu \mathrm{g}$ each (Jackson et al. 1997) and was supplemented with various amounts of glucose and acid-hydrolyzed casein. The corresponding carbon concentrations and $\mathrm{C}: \mathrm{N}$ ratios are shown in Table 1 for each culture medium tested. Low $\left(8 \mathrm{~g} \mathrm{~L}^{-1}\right)$ and high (36 $\mathrm{g} \mathrm{L}^{-1}$ ) carbon concentrations were tested in liquid media with different C:N ratios (10:1, 30:1, and 50:1) (Jackson \& Jaronski 2009). Carbon concentration and C:N ratio calculations were based on $40 \%$ carbon in glucose, and $53 \%$ carbon and $8 \%$ nitrogen in acid hydrolyzed casein, according to the manufacturer's specifications.

All cultures were grown in $100 \mathrm{~mL}$ of liquid medium using 250-mL baffled, Erlenmeyer flasks (Bellco Glass, Vineland, NJ, USA) incubated at $28^{\circ} \mathrm{C}$ and 300 rev. $\mathrm{min}^{-1}$ (rpm) in a rotary shaker incubator (INNOVA 4000, New Brunswick Scientific, Edison, NJ, USA). Flasks were hand-shaken frequently to prevent mycelial growth on the flask wall. For C:N ratio and carbon concentration studies, media were inoculated with a conidial suspension obtained from a 2-3 weeks old sporulated agar plate of $\mathrm{T}$. harzianum adjusted to deliver a final concentration of $5 \times 10^{5}$ conidia $\mathrm{mL}^{-1}$ in the medium. Two, 4 and $7 \mathrm{~d}$ after inoculation, $3 \mathrm{~mL}$ samples were taken to measure biomass, submerged conidia, MS concentration, desiccation tolerance and storage stability for submerged conidia and MS using previously described techniques (Jackson \& Jaronski 2009). For each experiment, duplicate samples were collected from each flask on each sampling date, and two duplicate flasks for each treatment were used in the studies. Experiments were independently repeated four times.

Because medium 6 (Table 1) produced high yields of both submerged conidia and MS, the $\mathrm{C}: \mathrm{N}$ ratio of this medium was used in subsequent studies to assess the impact of carbon and nitrogen sources on propagule formation. A medium formulation containing powdered molasses (BioSev, São Paulo,
SP, Brazil) with approximately $40 \%$ carbon was also tested as a substitute for glucose as the main carbon source. The protein-based agroindustrial by-products tested were soyflour (Toasted Nutrisoy ${ }^{\circledR}$, ADM Co., Decatur, IL, USA), cottonseed flour (Pharmamedia ${ }^{\circledR}$, Traders Protein, Memphis, TN, USA), yeast extract (Difco ${ }^{\circledR}$, Detroit, MI, USA) and corn steep liquor powder (Solulys ${ }^{\circledR}$ AST, Roquette Corporation, Gurnee, IL, USA) (Table 2). All liquid media were inoculated with conidia produced on PDA plates, as described previously, and subjected to two shaking frequencies (300 or $350 \mathrm{rpm}$ ) to check the impact of aeration rates on growth parameters. Nitrogen and agitation speed experiments followed the same protocol of evaluation previously described for the C:N ratio experiments. Each treatment had duplicate flasks and experiments were repeated three times.

To complete the nitrogen source studies, liquid media composed of a basal salts medium amended with cottonseed

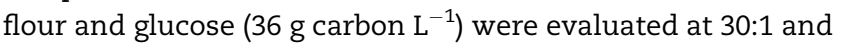
10:1 C:N ratios for MS production and dried MS storage stability. Liquid cultures were exclusively inoculated with a 3-dayold pre-culture of T. harzianum grown in medium 6 (Table 1 ) that delivered a final concentration of $5 \times 10^{6}$ submerged conidia $\mathrm{mL}^{-1}$, and then incubated for $4 \mathrm{~d}$. This assay followed the same fermentation protocol indicated above. Duplicate flasks were used for each treatment and the experiment was repeated three times.

\section{Formulation, desiccation tolerance, and storage stability}

Cultures of Trichoderma harzianum were harvested on day 7 by adding diatomaceous earth [DE (HYFLO ${ }^{\circledR}$, Celite Corp., Lompoc, CA, USA)] at a concentration of $5 \mathrm{~g} \mathrm{DE} 100 \mathrm{~mL}^{-1}$ culture broth to each flask that contained MS and/or submerged conidia and vacuum-filtering in a Buchner funnel using Whatman No. 1 filter paper to remove spent media. Diatomaceous earth was chosen because it is an inert compatible with most fungal propagules that does not hold water (desirable for storage stability studies). The resulting filter cake (fungal biomass + DE) was broken up by pulsing in a blender (Mini Prep ${ }^{\circledR}$ Plus, Cuisinart, Stamford, CT, USA), layered in Petri dish plates, and airdried overnight at $\sim 22{ }^{\circ} \mathrm{C}$ with a relative humidity (rh) of 50-60\%. Moisture contents of biomass + DE preparations were determined with a moisture analyzer (Mark II, Denver

Table 1 - Evaluation of submerged conidia, microsclerotia (MS), and biomass production by cultures of Trichoderma harzianum T-22 grown in media with different G:N ratios and carbon concentrations at $28{ }^{\circ} \mathrm{C}$ and 300 rpm in a rotary shaker incubator.

\begin{tabular}{|c|c|c|c|c|c|c|c|c|c|c|c|c|c|}
\hline \multirow[t]{2}{*}{ Medium } & \multirow[t]{2}{*}{$\begin{array}{l}\text { Carbon } \\
\left(\mathrm{g} \mathrm{L}^{-1}\right)\end{array}$} & \multirow[t]{2}{*}{$\begin{array}{l}\mathrm{C}: \mathrm{N} \\
\text { ratio }\end{array}$} & \multirow[t]{2}{*}{$\begin{array}{l}\text { Glucose } \\
\left(\mathrm{g} \mathrm{L}^{-1}\right)\end{array}$} & \multirow[t]{2}{*}{$\begin{array}{l}\text { Acid hydrolyzed } \\
\text { casein }\left(\mathrm{g} \mathrm{L}^{-1}\right)\end{array}$} & \multicolumn{3}{|c|}{$\begin{array}{l}\text { Submerged conidia } \\
\left(\times 10^{7} \text { conidia } \mathrm{mL}^{-1}\right)\end{array}$} & \multicolumn{3}{|c|}{$\begin{array}{c}\text { Microsclerotia } \\
\left(\times 10^{3} \mathrm{MS} \mathrm{mL}^{-1}\right)\end{array}$} & \multicolumn{3}{|c|}{$\begin{array}{l}\text { Biomass } \\
\left(\mathrm{mg} \mathrm{mL}^{-1}\right)\end{array}$} \\
\hline & & & & & Day 2 & Day 4 & Day 7 & Day 2 & Day 4 & Day 7 & Day 2 & Day 4 & Day 7 \\
\hline 1 & 8 & $10: 1$ & 10.0 & 10.0 & $6.5 \mathrm{a}^{\mathrm{a}}$ & $25.4 \mathrm{ab}$ & $27.1 \mathrm{bc}$ & $\mathrm{Ob}$ & $\mathrm{Ob}$ & $\mathrm{Ob}$ & $7.7 \mathrm{c}$ & $5.6 \mathrm{c}$ & $4.9 \mathrm{~d}$ \\
\hline 2 & 8 & $30: 1$ & 16.6 & 3.4 & 7.7 a & $32.1 \mathrm{a}$ & $33.6 \mathrm{~b}$ & $\mathrm{Ob}$ & $\mathrm{Ob}$ & $0 \mathrm{~b}$ & $5.0 \mathrm{~d}$ & $7.1 \mathrm{c}$ & $8.5 \mathrm{c}$ \\
\hline 3 & 8 & $50: 1$ & 18.0 & 2.0 & $3.4 \mathrm{~b}$ & $15.8 \mathrm{~b}$ & $20.5 c$ & $\mathrm{Ob}$ & $\mathrm{Ob}$ & $\mathrm{Ob}$ & $3.5 \mathrm{~d}$ & $4.7 \mathrm{~d}$ & $4.5 \mathrm{~d}$ \\
\hline 4 & 36 & 10:1 & 45.0 & 45.0 & $0 \mathrm{c}$ & $0 \mathrm{c}$ & $0 \mathrm{~d}$ & $27.8 \mathrm{a}$ & $48.3 \mathrm{a}$ & $15.3 \mathrm{a}$ & $10.0 \mathrm{~b}$ & $16.1 \mathrm{a}$ & $19.3 \mathrm{a}$ \\
\hline 5 & 36 & $30: 1$ & 75.0 & 15.0 & $0 \mathrm{c}$ & $0 \mathrm{c}$ & $39.1 \mathrm{~b}$ & $22.2 \mathrm{a}$ & $33.3 \mathrm{a}$ & $16.6 \mathrm{a}$ & $12.4 \mathrm{a}$ & $16.3 \mathrm{a}$ & $16.8 \mathrm{~b}$ \\
\hline 6 & 36 & $50: 1$ & 81.0 & 9.0 & $0 \mathrm{c}$ & 49.9 a & $95.5 \mathrm{a}$ & $32.8 \mathrm{a}$ & $25.8 \mathrm{a}$ & $25.9 \mathrm{a}$ & $10.4 \mathrm{~b}$ & $13.4 \mathrm{~b}$ & $16.3 \mathrm{~b}$ \\
\hline
\end{tabular}

a Means followed by different letters within a column are significantly different $(P \leq 0.05)$. 
Table 2 - Evaluation of submerged conidia, microsclerotia (MS), and biomass production by cultures of Trichoderma harzianum T-22 grown in a liquid culture medium with different nitrogen sources, a C:N ratio of 50:1, and carbon concentration of $36 \mathrm{~g} \mathrm{~L}^{-1}$. Cultures were incubated at $28{ }^{\circ} \mathrm{C}$ and either 300 or $350 \mathrm{rpm}$ in a rotary shaker incubator.

\begin{tabular}{|c|c|c|c|c|c|c|c|}
\hline \multirow{2}{*}{$\begin{array}{l}\text { Carbon } \\
\text { source }\end{array}$} & \multirow{2}{*}{$\begin{array}{l}\text { Nitrogen } \\
\text { source }\end{array}$} & \multicolumn{2}{|c|}{ Submerged conidia $\left(\times 10^{7}\right.$ conidia $\left.\mathrm{mL}^{-1}\right)$} & \multicolumn{2}{|c|}{ Microsclerotia $\left(\times 10^{3} \mathrm{MS} \mathrm{mL}^{-1}\right)$} & \multicolumn{2}{|c|}{ Biomass $\left(\mathrm{mg} \mathrm{mL}^{-1}\right)$} \\
\hline & & Day 2 & Day 4 & Day 2 & Day 4 & Day 2 & Day 4 \\
\hline Glucose & $\begin{array}{l}\text { Acid hydrolyzed } \\
\text { casein }\end{array}$ & $33.3 \mathrm{a}^{\mathrm{a}}$ & 80.5 a & $25.4 \mathrm{ab}$ & $31.9 \mathrm{ab}$ & $11.2 \mathrm{c}$ & $15.3 \mathrm{~b}$ \\
\hline Glucose & Soyflour & $4.6 \mathrm{~b}$ & $13.5 \mathrm{~b}$ & $8.8 \mathrm{~b}$ & $19.9 \mathrm{~b}$ & $15.5 \mathrm{~b}$ & 19.8 a \\
\hline Glucose & Cottonseed flour & $2.1 \mathrm{~b}$ & $4.5 \mathrm{c}$ & $66.0 \mathrm{a}$ & $115.4 \mathrm{a}$ & $15.5 \mathrm{~b}$ & 19.9 a \\
\hline Glucose & Yeast extract & $0 \mathrm{~d}$ & $24.5 b$ & $10.5 \mathrm{~b}$ & $20.8 \mathrm{~b}$ & $12.4 \mathrm{c}$ & $15.1 \mathrm{~b}$ \\
\hline Glucose & Corn steep liquor & $0 \mathrm{~d}$ & $14.6 \mathrm{~b}$ & $0.21 \mathrm{c}$ & $0.41 \mathrm{c}$ & $11.2 \mathrm{c}$ & $14.6 \mathrm{~b}$ \\
\hline Molasses & $\begin{array}{l}\text { Acid hydrolyzed } \\
\text { casein }\end{array}$ & $19.4 \mathrm{a}$ & $24.4 \mathrm{~b}$ & $0 \mathrm{~d}$ & $0 \mathrm{~d}$ & $19.5 \mathrm{a}$ & $21.8 \mathrm{a}$ \\
\hline
\end{tabular}

Instruments, Arvada, CO, USA) along with their corresponding water activities $\left(\mathrm{a}_{\mathrm{w}}\right)$, measured at an equilibrium temperature of $25^{\circ} \mathrm{C}$ (AquaLab series 4TEV, Decagon Devices, Pullman, WA, USA). When formulations of T. harzianum were dried to a moisture content of less than $4 \%$ (water activity $<0.35$ ) by turning the rh in the chamber down to $15-20 \%$, the dried formulations were vacuum packed in nylon polyethylene bags $(15.3 \times 21.8 \mathrm{~cm})$ with a vacuum packer (Multivac C 100, Sepp Haggenmüller, Wolfertschwen-den, Germany) and further stored at $4{ }^{\circ} \mathrm{C}$.

To evaluate the storage stability of T. harzianum MS at $25^{\circ} \mathrm{C}$ and $4{ }^{\circ} \mathrm{C}$, a hundred $\mathrm{mL}$ cultures of $\mathrm{T}$. harzianum $\mathrm{T}-22$ were grown in medium 10:1 and 30:1 C:N ratio with cottonseed flour as the nitrogen source, harvested on day 4 , formulated with $5 \% \mathrm{DE}(\mathrm{w} / \mathrm{v})$, and air-dried to less than $4 \%$ moisture. Afterward, air dried MS formulations were vacuum packed in $15 \times 22 \mathrm{~cm}$ aluminized Mylar bags (PAKVF4, IMPAK Corporation, Los Angeles, CA, USA). Microsclerotia viability and submerged conidia production was evaluated using a previously described method (Jackson \& Jaronski 2009).

For submerged conidia viability assays, $0.01 \mathrm{~g}$ of each dried submerged conidia - DE formulation was diluted in $10 \mathrm{~mL}$ of $0.04 \%$ Tween $80\left(\right.$ Sigma $\left.^{\circledR}\right)$, vortexed for $1 \mathrm{~min}$, and allowed $\mathrm{DE}$ particles to settle for $1 \mathrm{~min}$. Two aliquots of $100 \mu \mathrm{L}$ of the supernatant containing mainly submerged conidia were inoculated on water agar ( $1 \%$ agar w/v) plates to deliver approximately $1 \times 10^{5}$ submerged conidia per plate. Preliminary studies revealed no significant differences between PDA and water agar medium for germination assessment (data not shown). Germination was assessed microscopically by evaluating 200 submerged conidia per water agar plate under an inverted microscope (Olympus IMT-2) after $16 \mathrm{~h}$ incubation at $25{ }^{\circ} \mathrm{C}$. Submerged conidia were considered germinated when the germ tube was longer than the diameter of the conidium. Desiccation tolerance was expressed as percentage submerged conidia survival and each treatment replicate had two subsamples. Further evaluations were conducted monthly until spore viability was less than $40 \%$.

\section{Bioefficacy of MS granules on damping-off disease}

Bioassays with Cantaloupe melon (cv. 'Hales Best') were conducted to assess the bioefficacy of Trichoderma harzianum (T-
22) MS produced in liquid culture (36 g carbon $\mathrm{L}^{-1}$; 30:1 C:N ratio; harvested on day 4 and formulated with $5 \%$ diatomaceous earth [Hyflo $\left.\left.{ }^{\circledR}\right]\right)$. The damping-off pathogen, Rhizoctonia solani NRRL 22805 (Agricultural Research Service (NRRL) Culture Collection) was grown in Petri plates of CV8 agar (Schisler \& Slininger 1994) for 3 day at $25^{\circ} \mathrm{C}$. In a $100 \mathrm{~mL}$ Erlenmeyer flask, $25 \mathrm{~cm}^{3}$ ( $\left.\sim 8.5 \mathrm{~g}\right)$ of washed and dried pulverized rice hulls ( $1 \mathrm{~mm}^{3}$ particles) were combined with $6 \mathrm{~mL}$ of $10 \%$ tryptic soy broth (Difco Laboratories, Detroit, MI, USA) and $12 \mathrm{~mL}$ of double-deionized water. Flasks were autoclaved for $30 \mathrm{~min}$ on three consecutive days. The sterile rice hulls were then inoculated with ten, $1 \mathrm{~mm}^{2}$ colonized-agar plugs of $\mathrm{R}$. solani, incubated at $25{ }^{\circ} \mathrm{C}$, and shaken daily for $8 \mathrm{~d}$ to assure homogenous colonization of individual particles (Harris et al. 1993). One day prior to experimentation, a small sample of the infested rice hulls was plated on CV8 medium to assure culture purity. Bioassay experiment treatments consisted of R. solani alone (1.5 and $0.63 \mathrm{~g}$ ) of infested rice hulls thoroughly mixed with $1000 \mathrm{~cm}^{3}$ or $1 \mathrm{~L}^{1}$ of non-steamed Terra-lite RediEarth ${ }^{\circledR}$ potting mix (W.R. Grace, Cambridge, MA, USA), R. solani (both inoculum doses) $+\mathrm{T}$. harzianum (0.4 g air-dried MS $\mathrm{L}^{-1}$ of potting mix), $\mathrm{T}$. harzianum only and a noninoculated control. This formulation of T. harzianum was free of submerged conidia and contained MS only. These treatments were homogenized in plastic bags and shaken vigourously prior to sowing. The experiments were conducted in punnets $(18 \times 13 \times 5.5 \mathrm{~cm})$ containing six cells, and each treatment had two replications. In each cell $(5.5 \times 5 \times 5.5 \mathrm{~cm})$, a small square of paper (Wypall ${ }^{\circledR}$, Kimberly-Clark Professional, USA) was placed on the bottom to prevent potting mix from leaking out of punnets. One quarter of a cup $\left(59.15 \mathrm{~cm}^{3}\right)$ of non-sterile, uninoculated potting medium was added to the bottom of each cell. Forty-four $\mathrm{cm}^{3}$ of the single or mixed treatments (infested with $R$. solani and/or treated with $T$. harzianum) were then layered on top of the uninoculated potting mix. Three melon seeds were then sown within the treatment mix layer ( 36 seeds per treatment) at a depth of $0.5 \mathrm{~cm}$ and then placed in a growth chamber at $26^{\circ} \mathrm{C}$ and $14 \mathrm{~h}$ photophase. Punnets were top-watered the first $2 \mathrm{~d}$ after sowing and then kept in separate plastic trays with adequate water to maintain potting mix wetness. Evaluations were made daily to enumerate the proportion of emerged seedlings and dead seedlings showing symptoms of damping-off caused by 
R. solani until day 15 after sowing. The experiment was repeated three times on different days with time considered a block effect. From those seedlings showing symptoms of damping-off, samples from the necrotic tissue immediately above the root system (i.e., hypocotyl stem) were cut and surface sterilized with a sodium hypochlorite solution $(0.35 \% \mathrm{v} / \mathrm{v})$ and rinsed three times with sterile double-deionized water. Samples were then plated on Martin's rose-bengal (MRB) agar (Martin 1950) to confirm the association of R. solani with damped off seedlings. To ascertain if $\mathrm{T}$. harzianum was able to colonize the root system of melon, samples of root tissues from seedlings grown in potting mix treated only with this fungus were surface sterilized, as previously mentioned, and then plated on MRB agar.

\section{Experimental design and statistical analysis}

Each experiment was conducted with a completely randomized design and repeated at least three times and further combined for analysis. We used $R$ ( $R$ Development Core Team 2012) and lme4 package (Bates et al. 2012) to perform linear mixed effects analysis for repeated measures data addressing the effects of culture medium and time on biomass accumulation, submerged conidia concentration, MS concentration, conidial production from dried MS, and conidial viability. For liquid fermentation studies, we entered treatment (i.e., culture medium), time (i.e., fermentation day or storage period) and their interaction term as fixed effects into the model. As random effects, we had shake flask (i.e., subject or replicate) with repeated observations over time and experimental repetition to account for any variation among experiments conducted at different dates. Likelihood-ratio chi-square test was employed to address the significance of fixed effects and their interaction in the linear mixed models by estimating their $P$-values by comparing nested models (Pinheiro \& Bates 2000). Submerged conidia and MS production data were transformed by $\log _{10}(x+1)$ when necessary to meet the data normality and homogeneity assumptions prior to analysis. Post-hoc pairwise comparisons were carried out using the function ghlt in the multcomp package to compare treatments, correcting $P$-values for multiple comparisons by the single-step method. Submerged conidial viability (\% germination) recorded before and after air-drying (i.e., two dependent samples) were compared by paired t-Student test to account for the impact of desiccation tolerance on submerged conidial survival within each treatment. For the longitudinal dataset on storage stability of MS, measured by conidia production over time, treatment (culture media) and time (months) were fitted as fixed effects, while sampling packages (i.e., subjects) were considered a random effect in a linear mixed model. Then slopes for the storage stability curves were compared using a contrast matrix to assess differences among the treatments. Submerged conidia storage stability data were fitted by an exponential decay model using the function nls, and comparisons between nonlinear models were made via the sum-ofsquares reduction test (Ratkowsky 1990).

The effect of soil treatments on the proportion of melon seedlings killed by damping-off caused by $R$. solani was assessed by survival analysis (Kaplan \& Meier 1958). Seedlings surviving beyond day 15 were considered censored. Statistically significant differences between survival curves for treatments were estimated by the log-rank test (survival package) with $P$-values adjusted by Bonferroni. Proportion data on total seedling emerged and healthy seedling recorded at day 15 were analysed by a generalized linear mixed model (glmer) with treatments as fixed effect, while punnets (replicates) and bioassays (experimental repetitions) were scored as random effects.

\section{Results}

\section{Impact of nutritional environment on propagule formation}

Under shake-flask culture conditions, the formation of submerged conidia and MS of Trichoderma harzianum T-22 was observed and monitored over a 7-day-fermentation period in liquid culture media with different $\mathrm{C}: \mathrm{N}$ ratios. Microsclerotia of $\mathrm{T}$. harzianum were exclusively formed and developed in high carbon media $\left(36 \mathrm{~g} \mathrm{~L}^{-1}\right)$, regardless of the C:N ratio tested. The richest medium (\# 4) with a 10:1 C:N ratio lacked the production of submerged conidia, but it rather promoted the development of MS. Fully formed MS of T. harzianum were $90-600 \mu \mathrm{m}$ in diameter (Fig S1). According to the linear mixed effects model accounting for repeated measures over time, MS production by $T$. harzianum was affected by both culture medium $\left(\chi_{(15)}^{2}=264.84, P<0.0001\right)$ and fermentation time $\left(\chi^{2}{ }_{(12)}=32.09, P=0.0013\right)$. The interaction between fermentation time and culture medium contributed to the variation in production rates of MS $\left(\chi_{(12)}^{2}=20.78, P=0.023\right)$ (Table 1). In general, more MS were produced by day 4 in all culture media $\left(2.6-4.8 \times 10^{4} \mathrm{~mL}^{-1}\right)$, with fewer MS observed on day 7 , likely due to MS aggregation. Microsclerotia of T. harzianum began to form after $48 \mathrm{~h}$ growth with MS becoming more well-defined and compact by day 4 and subsequent melanization by day 7 . The greenish colour of the conidia produced in liquid culture made it difficult to determine the extent of melanization among the media tested (Fig S1). While MS were more compact and melanized, these structures presented short hyphal extensions emanating from their surface.

Submerged conidiation was supported by all media tested, except for medium with high carbon and nitrogen levels (36 $\mathrm{g} \mathrm{L}^{-1}$ carbon, 10:1 C:N ratio) that yielded only MS. These submerged conidia were formed by conidiogenous cells (e.g., phialides) attached to submerged hyphae in early stages (day 2) of growth especially when the fungus was cultivated in a weak medium (8 $\mathrm{g}_{\text {carbon } \mathrm{L}^{-1}}$ ). After $4 \mathrm{~d}$ growth, submerged conidia were produced in high concentrations in those cultures with high carbon levels and lower nitrogen concentrations (50:1 and 30:1 C:N ratios; Table 1). Production rates for submerged conidia were significantly affected by the interaction of culture medium $\times$ fermentation time $\left(\chi_{(15)}^{2}=904.97\right.$, $P<0.0001)$. A significant overall increase in submerged conidial production over time was noted in all culture media $\left(\chi^{2}{ }_{(12)}=980.8, P<0.0001\right)$, with higher numbers of submerged conidia achieved by day 7. Media with low carbon concentration reached maximum submerged conidial production by day $4\left(1.6-3.2 \times 10^{8}\right.$ conidia $\left.\mathrm{mL}^{-1}\right)$, while carbon-rich media 
5 and 6 attained maximum production by day $7\left(3.9-9.7 \times 10^{8}\right.$ conidia $\left.\mathrm{mL}^{-1}\right)$. Higher submerged conidia concentrations observed in carbon-rich media were expected as higher availability of nutrients in these media promoted better vegetative growth and subsequent conidiation compared to carbon-limited media $\left(\chi_{(15)}^{2}=1028.2, P<0.0001\right)$. As a result, cultures of $\mathrm{T}$. harzianum grown in carbon-limited media (media 1, 2, and 3) produced high concentrations of submerged conidia within $2 \mathrm{~d}\left(6.5-7.7 \times 10^{7}\right.$ conidia $\left.\mathrm{mL}^{-1}\right)$, whereas me-

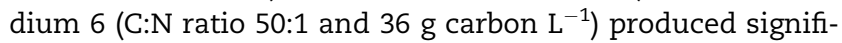
cantly more submerged conidia $\left(9.7 \times 10^{8}\right.$ conidia $\left.\mathrm{mL}^{-1}\right)$ by day 7.

Biomass accumulation ( $\mathrm{mg} \mathrm{mL}^{-1}$ ) followed the predicted pattern in that fungal growth in carbon-limited media $\left(8 \mathrm{~g} \mathrm{~L}^{-1}\right)$ resulted in less biomass when compared to cultures grown in media with $36 \mathrm{~g} \mathrm{~L}^{-1}$ carbon, regardless of the $\mathrm{C}: \mathrm{N}$ ratio (Table 1). This difference was significant by the interaction of culture medium and fermentation time $\left(\chi_{(10)}^{2}=122.95, P<0.0001\right)$. Media richer in carbon supply increased biomass over time $\left(\chi^{2}{ }_{(12)}=185.4, P<0.0001\right)$. As expected, rich-medium with 10:1 C:N ratio produced the greatest biomass at all evaluation days $\left(\chi_{(15)}^{2}=247.14\right.$, $P<0.0001)$. Fungal biomass decreased linearly with fermentation days for the poorest medium in carbon (medium 1). Microscopic examination revealed that hyphal growth increased over time in carbon-rich media followed by the rapid formation of MS.

\section{Desiccation tolerance and storage stability of Trichoderma harzianum propagules}

After $7 \mathrm{~d}$ growth, all Trichoderma harzianum cultures from the C:N ratio studies were air dried to $0.8-3.8 \%$ moisture with corresponding water activity $\left(\mathrm{a}_{\mathrm{w}}\right)$ measurements in a range of $0.35-0.41$, and vacuum-packaged for storage at $4{ }^{\circ} \mathrm{C}$. Regardless of the production medium, $100 \%$ of dried MS granules germinated hyphally after rehydration and incubation for $24 \mathrm{~h}$. Subsequently, aerial conidia were produced on hyphal extensions and on the surface of MS granules as noted by their light greenish colouration (Fig S1). Immediately after air drying, it was observed that culture medium significantly affected conidial production by MS $\left(\chi^{2}{ }_{(2)}=31.08, P<0.0001\right)$ (Fig 1). Microsclerotial granules derived from media with a 10:1 CN ratio yielded $35 \%$ and $52 \%$ more conidia compared with MS granules harvested from 30:1 and 50:1 C:N ratio media, respectively. In long-term storage stability studies, conidial production was significantly affected by both culture medium $\left(\chi_{(4)}^{2}=98.4, P<0.0001\right)$ and storage period $\left(\chi^{2}(3)=47.2, P<0.0001\right)$ (Fig 1). The 12-month storage stability pattern for rich-carbon medium at 10:1 C:N ratio (medium 4) produced significantly more conidia per MS granules than medium 5 (30:1 C:N ratio) or 6 (50:1 C:N ratio) $\left(\chi^{2}{ }_{(2)}=13.23, P=0.0013\right)$. Conidial production by MS granules harvested from media with a 10:1 C:N ratio and $36 \mathrm{~g}$ carbon $\mathrm{L}^{-1}$ (medium 4) remained high $\left(1.13-2.03 \times 10^{10}\right.$ conidia $\mathrm{g}^{-1}$ ) over $12 \mathrm{~m}$ storage with a significant increase in conidial production after $6 \mathrm{~m}$ storage. Microsclerotial granules from the 30:1 C:N ratio medium exhibited the second highest conidial production in contrast to the lowest yield noted by medium 6 (50:1 C:N ratio). Regardless of the differences in conidial

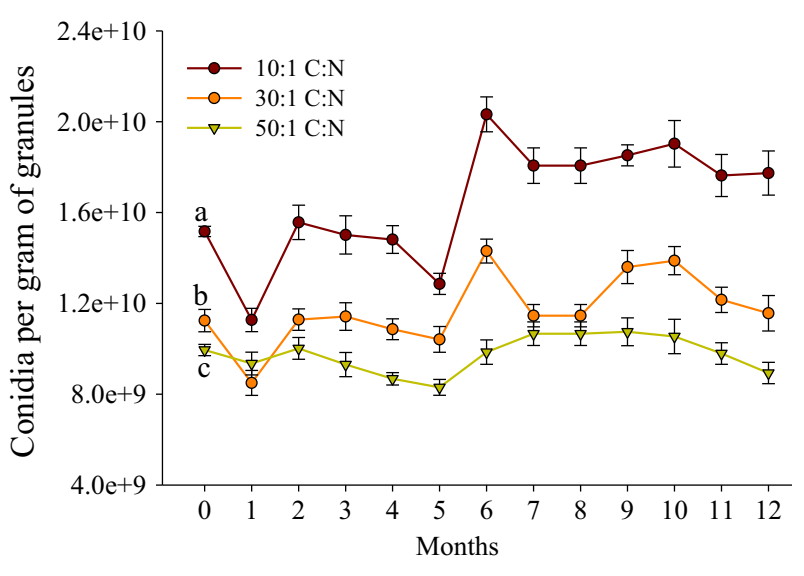

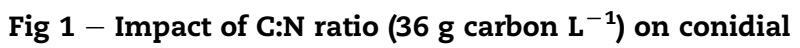
production by dried microsclerotial (MS) granules of Trichoderma harzianum T-22 formulated with $5 \%$ diatomaceous earth after air-drying and during long-term storage under refrigerated conditions $\left(4^{\circ} \mathrm{C}\right)$. Conidial production was assessed after MS granules being incubated on water agar for $7 \mathrm{~d}$ at $25^{\circ} \mathrm{C}$. Means $( \pm \mathrm{SE})$ at time ' 0 ' referred to desiccation tolerance and different letters indicate significant differences $(P \leq 0.05)$.

production by MS granules from various culture media, conidial production for each treatment did not decrease or lose yield over time, which indicates that these MS granules remained remarkably stable under cool storage for at least $12 \mathrm{~m}$.

The viability and stability of submerged conidia produced in different culture media after $7 \mathrm{~d}$ growth were assessed before and after drying and then 1, 2, and $12 \mathrm{~m}$ after storage at $4{ }^{\circ} \mathrm{C}$. Only submerged conidia produced in medium 2 (8 g carbon $\mathrm{L}^{-1}, 30: 1 \mathrm{C}: \mathrm{N}$ ratio) did not suffer a significant reduction in germination after drying when compared to fresh submerged conidia (paired $t_{(5)}=1.23, P=0.273$ ), whereas submerged conidia from the other media tested exhibited a significant lower desiccation tolerance (paired t-test: $P<0.01$ ) (Fig 2). Fresh submerged conidia from medium 1 (limited-carbon) had the highest germination rate $(84.3 \%$ viability) for fresh submerged conidia but the poorest desiccation tolerance $(2.1 \%$ viability) (Fig 2). A nonlinear exponential decay model was used to explain the relationship between storage time and submerged conidial viability in each treatment with a confidence of $R^{2}=0.75-0.81$. According to the models fitted to our experimental viability data recorded over time, half-lives of stored submerged conidia were estimated in 1.93, 1.05, 1.26, and $1.81 \mathrm{~m}$ when harvested from media 2, 3, 5, and 6, respectively. Medium 2 (low carbon and 30:1 C:N ratio) and 6 (high carbon, low nitrogen, 50:1 C:N ratio) displayed the highest germination rates by month 2, although viability decreased significantly after 12 $\mathrm{m}$ storage with submerged conidia from medium 2 (low carbon and 30:1 C:N ratio) remaining the most viable (41\% survival). A comparison of survival curves confirmed that submerged conidia harvested from medium two attained the longest survival $(P<0.01)$. 


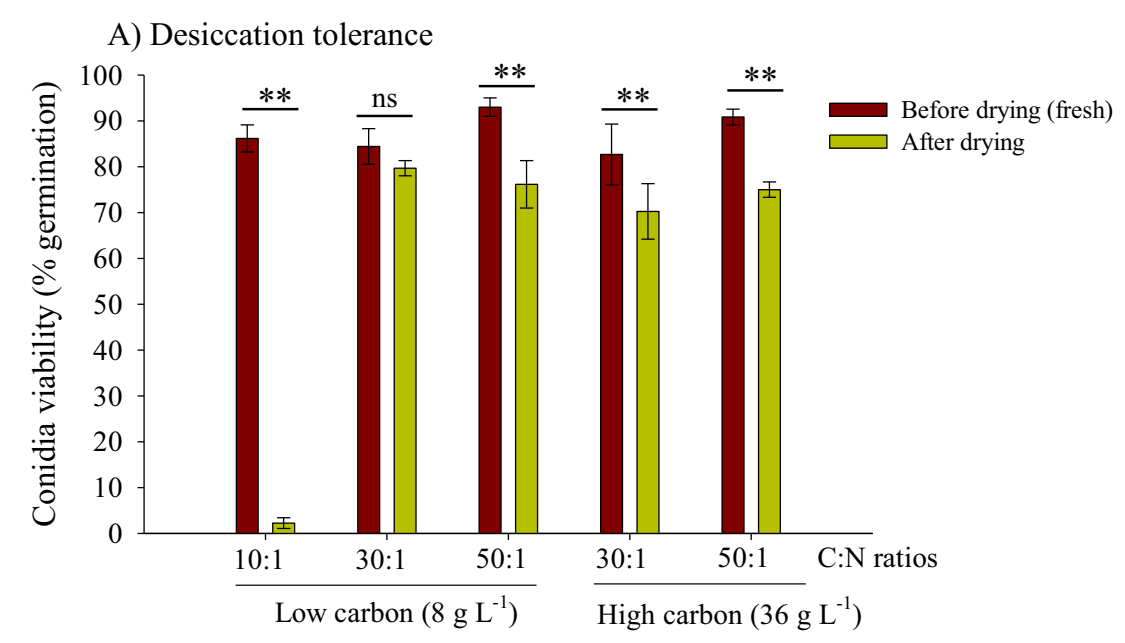

B) Storage stability

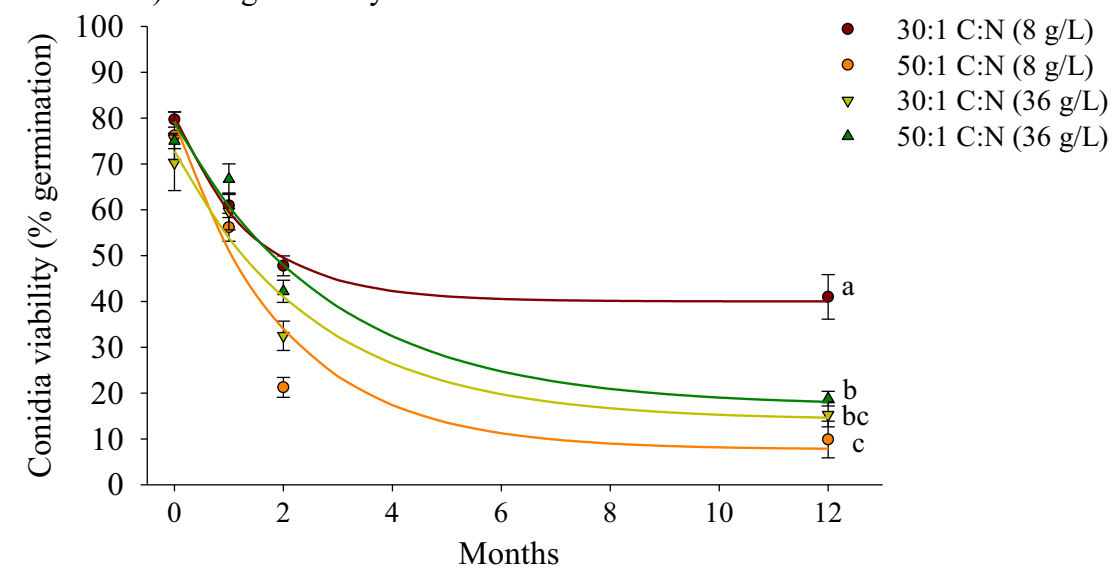

Fig 2 - Desiccation tolerance (A) and storage stability (B) of Trichoderma harzianum T-22 submerged conidia produced in various media. Dried submerged conidia were vacuum packed and stored at $4{ }^{\circ} \mathrm{C}$. Conidial germination of dried submerged conidia was assessed on water agar after $16 \mathrm{~h}$ incubation at $25{ }^{\circ} \mathrm{C}$. (A) Pair-wise comparisons between viability rates (means \pm SE) before and after air-drying; paired t-Student test at $P \leq 0.05\left(^{*}\right), P \leq 0.01\left(^{* *}\right.$ ) or not significant (ns). (B) full circles represent means $( \pm \mathrm{SE})$ while lines are the fitted data by a exponential decay model: $y=40+40.3 \exp (-0.72 \times$ time) $\left(R^{2}=0.75\right)\left[30: 1 \mathrm{C}: \mathrm{N}, 8 \mathrm{~g} \mathrm{~L}^{-1}\right], \mathrm{y}=7.7+71.6 \exp (-0.5 \times$ time $)\left(R^{2}=0.80\right)$ [50:1C:N, $\left.8 \mathrm{~g} \mathrm{~L}^{-1}\right], \mathrm{y}=14.1+58.7 \exp (-0.39 \times$ time $)$ $\left(R^{2}=0.79\right)\left[30: 1 \mathrm{C}: \mathrm{N}, 36 \mathrm{~g} \mathrm{~L}^{-1}\right]$, and $\mathrm{y}=17.2+61.9 \exp (-0.35 \times$ time $)\left(R^{2}=0.81\right)$ [50:1C:N, $\left.36 \mathrm{~g} \mathrm{~L}^{-1}\right]$. Viability decay curves were compared by the sum-of-squares reduction test and different letters indicate significant difference between curves at $P \leq 0.05$.

Effect of agitation speed and nitrogen sources on Trichoderma harzianum liquid fermentation

Increasing the agitation speed from 300 to $350 \mathrm{rpm}$ did not affect the production of submerged conidia $\left(\chi_{(1)}^{2}=3.11\right.$, $P=0.08)$, MS yields $\left(\chi^{2}{ }_{(1)}=1.06, P=0.302\right)$, or biomass accumulation $\left(\chi_{(1)}^{2}=2.16, P=0.142\right)$. Thus, the experimental data obtained during growth at 300 and $350 \mathrm{rpm}$ were grouped together for analysis. Fermentation studies with different nitrogen sources at nutrient concentrations conducive to MS formation revealed that MS yields occurred to varying degrees with all nitrogen sources tested (Table 2). Molasses in place of glucose as the carbon and energy source did not promote MS formation. All carbon and nitrogen sources tested at 50:1 (C:N ratio) with $36 \mathrm{~g}$ carbon $\mathrm{L}^{-1}$ resulted in the production of both submerged conidia and MS, with the exception for the medium amended with molasses that exclusively rendered submerged conidia. Based on MS yields, cottonseed flour com-

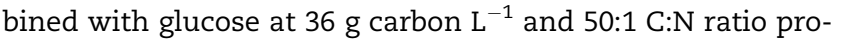
duced significantly higher numbers of MS from day 2-4 compared with other nitrogen substrates tested $\left(\chi_{(10)}^{2}=137.56, P<0.0001\right.$, Table 2). Overall, MS formation increased over fermentation time, regardless of the nitrogen source employed $\left(\chi^{2}{ }_{(6)}=34.14, P<0.0001\right)$. Interaction of culture medium $\times$ days of fermentation had a significant impact on MS production $\left(\chi_{(5)}^{2}=13.17, P=0.022\right)$, indicating that growth rates for MS differed across culture media.

Media composition had a significant effect on the formation and melanization of Trichoderma harzianum MS particularly when different nitrogen sources were used. For 
example, MS produced with cottonseed flour (Pharmamedia ${ }^{\circledR}$ ) were highly melanized as indicated by their darker colouration; whereas those MS produced with acid hydrolyzed casein were lighter colour and less compact after $4 \mathrm{~d}$ growth. Furthermore, MS were formed by day 4 as these propagules became more distinct, melanized and compact, especially when grown with cottonseed flour. No MS were formed in medium amended with molasses + acid hydrolyzed casein, while MS numbers were reduced in media containing glucose + corn steep liquor ( $\leq 400 \mathrm{MS} \mathrm{mL}^{-1}$ ).

For submerged conidia, production was significantly influenced by the interaction between medium composition and fermentation time $\left(\chi^{2}(5)=406.3, P<0.0001\right)$. Submerged conidial production increased over time in all media tested $\left(\chi^{2}{ }_{(6)}=453.21, P<0.0001\right)$ other than the molasses + acid hydrolyzed casein medium. Cultures grown in media with glucose + cottonseed flour produced the highest concentration of submerged conidia by day $4\left(\chi_{(10)}^{2}=472.6\right.$, $P<0.0001)$. The nitrogen source and fermentation time affected independently the biomass accumulation due to the non-significant interaction $\left(\chi_{(5)}^{2}=7.92, P=0.161\right)$. Cultures grown in media containing molasses + acid hydrolyzed casein produced more fungal biomass $\left(\chi_{(10)}^{2}=98.24, P<0.0001\right)$ than cultures grown in media amended with glucose + yeast extract, glucose + acid hydrolyzed casein or glucose + corn steep liquor (Table 2).

Using cottonseed flour as the nitrogen source, MS production was significantly affected by both $\mathrm{C}: \mathrm{N}$ ratio $\left(\chi_{(2)}^{2}=6.5\right.$, $P=0.039)$ and fermentation time $\left(\chi^{2}{ }_{(2)}=16.51, P=0.0003\right)$, but not by their interaction term $\left(\chi^{2}(1)=2.05, P=0.152\right)$, indicating that growth rates were similar. No submerged conidia were produced under these culture conditions. More MS were produced by day 2 in cultures grown in media with a 10:1 C:N ratio compared to media with a 30:1 C:N ratio, whereas by day $3 \mathrm{MS}$ concentrations were lower in both media with no statistical difference (Table 3). Trichoderma harzianum grew faster producing greater biomass in media with more nitrogen and a 10:1 C:N ratio. There was a significant effect of both C:N ratio $\left(\chi^{2}{ }_{(2)}=66.25, P<0.0001\right)$ and fermentation time $\left(\chi^{2}{ }_{(2)}=26.34, P<0.0001\right)$ and their interaction $\left(\chi^{2}{ }_{(2)}=10.8, P=0.001\right)$ on biomass accumulation. In agreement with these results, dried MS granules from cultures grown in 10:1 C:N ratio media produced $30 \%$ more conidia in comparison to MS granules from cultures grown in 30:1 C:N ratio medium $\left(\chi_{(1)}^{2}=17.95, P<0.0001\right)$. Nonetheless, MS granules from both media were desiccation tolerant showing $100 \%$ hyphal germination after $24 \mathrm{~h}$ incubation. The storage stability study revealed that conidial production by MS granules was generally higher in medium with higher nitrogen content (10:1 C:N ratio) $\left(\chi_{(10)}^{2}=47.14, P<0.0001\right)$ and variable across temperature and storage month $\left(\chi^{2}{ }_{(16)}=46.63, P<0.0001\right)$ (Fig 3). The only evidence of decline in conidial production over time for MS granules was achieved by 10:1 C:N ratio stored at $25^{\circ} \mathrm{C}\left(\chi_{(8)}^{2}=25.16, P=0.0015\right)$. Interestingly, conidial yield was greater when stored at $25^{\circ} \mathrm{C}$ than $4{ }^{\circ} \mathrm{C}$ in particular from media with 30:1 C:N ratio $\left(\chi^{2}{ }_{(10)}=32.93, P=0.0003\right)$.

\section{Bioassays with damping-off}

Treating potting mix with Rhizoctonia solani reduced the percentage of melon seeds that emerged and also resulted in delayed emergence compared to the negative (uninoculated) control or seeds treated only with Trichoderma harzianum (i.e., positive control) $\left(\chi_{(5)}^{2}=44.37, P<0.0001\right)$. The higher inoculum rate of $R$. solani impaired seed germination to a greater extent compared to the other treatments (data not shown). By contrast, the percent emergence of melon seedlings were significantly increased in the presence of the antagonism for the highest level of $R$. solani inoculum and arithmetically increased, though not significantly for the treatment with the lower level of $R$. solani inoculum (Table 4). Disease reduction for treatments that combined $R$. solani and T. harzianum was calculated based on the disease levels obtained when seeds were grown in potting mix infested with the same rate of pathogen inoculum alone. Thus, the presence of $T$. harzianum MS substantially increased the proportion of healthy seedlings at day $15\left(\chi^{2}{ }_{(5)}=54.09, P<0.0001\right)$. The progression of damping-off over time was more pronounced in both treatments with only $R$. solani (log-rank test: $\chi_{(5)}^{2}=194.7$, $P<0.0001$ ) (Fig 4). By contrast, the antagonist reduced the level of post-emergence damping-off by 90 and $100 \%$, respectively, compared to soil inoculated with the high and low level of $R$. solani only. Interestingly, the addition of T. harzianum MS granules to either inoculum level of $R$. solani significantly increased the likelihood of melon seedling survival to damping-off compared to the respective treatments without the antagonist. Seedlings with damping-off symptoms were confirmed to be infected with $R$. solani as revealed by the characteristic morphology of fungal growth from surface sterilized root and hypocotyl tissues plated on MRB agar (Fig S2). Conversely, soil samples and surface sterilized root and stem fragments from potting mix treated with $\mathrm{T}$. harzianum showed outgrowth

Table 3 - - Evaluation of C:N ratio on microsclerotia (MS) and biomass production by cultures of Trichoderma harzianum T-

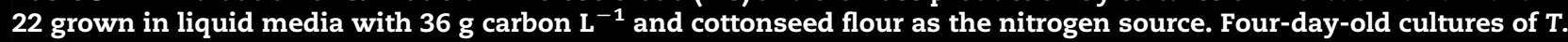
harzianum were mixed with diatomaceous earth and air-dried to less than $4 \%$ moisture.

\begin{tabular}{lcccccc} 
C:N ratio & \multicolumn{2}{c}{ Microsclerotia $\left(\times 10^{3} \mathrm{MS} \mathrm{mL}^{-1}\right)$} & & \multicolumn{2}{c}{ Biomass $\left(\mathrm{mg} \mathrm{mL}^{-1}\right)$} & Aerial conidia production $\left(\times 10^{10} \mathrm{~g}^{-1} \mathrm{dried} \mathrm{MS} \mathrm{granule}^{\mathrm{a}}\right.$ \\
\cline { 2 - 3 } & Day 2 & Day 4 & & Day 2 & Day 4 & \\
\hline $10: 1$ & $5.9 \mathrm{a}^{\mathrm{b}}$ & $3.6 \mathrm{a}$ & & $27.8 \mathrm{a}$ & $28.6 \mathrm{a}$ & $1.7 \mathrm{a}$ \\
$30: 1$ & $4.4 \mathrm{~b}$ & $3.3 \mathrm{a}$ & & $16.3 \mathrm{~b}$ & $19.0 \mathrm{~b}$ & $1.3 \mathrm{~b}$
\end{tabular}

a Conidial production on water agar by rehydrated MS granules after $7 \mathrm{~d}$ incubation at $25^{\circ} \mathrm{C}$.

$\mathrm{b}$ Means within a column that are not followed by the same letter are significantly different $(P \leq 0.05)$. 


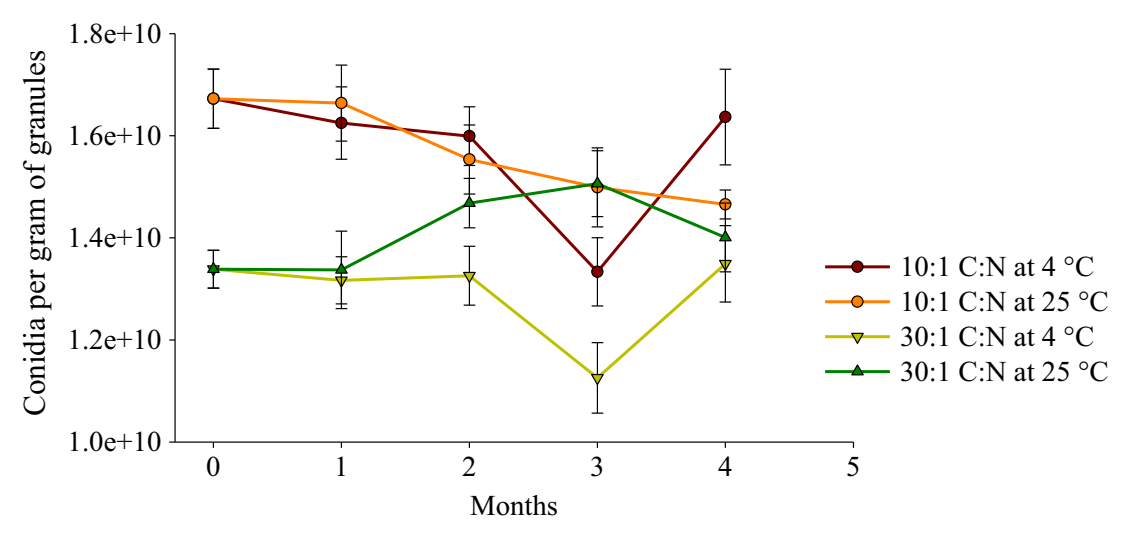

Fig 3 - Storage stability of microsclerotial (MS) granules of Trichoderma harzianum T-22 produced in various liquid media using cottonseed flour as the nitrogen source. Cultures were harvested after $4 \mathrm{~d}$ growth at $28{ }^{\circ} \mathrm{C}$ and $350 \mathrm{rpm}$ in a rotary shaker incubator. Microsclerotia-containing cultures were mixed with diatomaceous earth, dewatered, and air dried to less than $4 \%$ moisture and stored vacuum packed at $4{ }^{\circ} \mathrm{C}$ or $25^{\circ} \mathrm{C}$.

of $\mathrm{T}$. harzianum when plated on MRB, indicating that this biocontrol fungus maintained high populations in inoculated potting mix and was closely associated with these plant tissues (Fig S2).

\section{Discussion}

Our studies showed for the first time that Trichoderma harzianum produces MS in liquid culture. Under appropriate nutritional and environmental conditions, cultures of $T$. harzianum T-22 produced submerged conidia and MS with the latter propagule shown to effectively control dampingoff by Rhizoctonia solani. Although Trichoderma may be able to form MS in nature, to our knowledge, this has not been reported yet. Studies with other fungi have shown that the

Table 4 - Percentage of cantaloupe seeds that emerged and percentage that developed into healthy seedlings in growth chamber bioassays after treatments with Trichoderma harzianum T-22 (0.4 g formulated granule $\mathrm{L}^{-1}$ potting $\mathrm{mix}$ ) to control $R$. solani inoculated at two rates ( 0.63 and $1.5 \mathrm{~g} \mathrm{~L}^{-1}$ ) in non-sterile potting medium $15 \mathrm{~d}$ after sowing.

\begin{tabular}{lcc} 
Soil treatment & $\begin{array}{c}\text { Total } \\
\text { emergence } \\
(\%)^{\mathrm{a}}\end{array}$ & $\begin{array}{c}\text { Healthy } \\
\text { seedlings } \\
(\%)^{\mathrm{b}}\end{array}$ \\
\hline Control (uninoculated) & $84.3 \mathrm{a}^{\mathrm{c}}$ & $84.3 \mathrm{a}$ \\
Control - T. harzianum & $84.3 \mathrm{a}$ & $84.3 \mathrm{a}$ \\
R. solani 0.63 g L & $61.1 \mathrm{~b}$ & $33.3 \mathrm{c}$ \\
R. solani 1.5 g L & $11.1 \mathrm{c}$ & $2.8 \mathrm{~d}$ \\
R. solani 0.63 g L & $75.9 \mathrm{ab}$ & $75.9 \mathrm{ab}$ \\
R. solani 1.5 $\mathrm{g} \mathrm{L}^{-1}+$ T. harzianum & $78.9 \mathrm{~b}$ & $58.3 \mathrm{~b}$ \\
\hline
\end{tabular}

a Percentage of seedling emergence out of 18 seeds sown per punnet averaged across three independent experiments.

b Percentage of 18 seeds that developed healthy seedlings averaged across three independent experiments.

c Means within a column that are not followed by the same letter are significantly different $(P \leq 0.05)$. composition and fitness of propagules produced in liquid media can be affected by nutritional conditions such as nitrogen and carbon concentration or C:N ratio (Schisler et al. 1991; Jackson \& Schisler 1992; Jackson \& Jaronski 2009). We have demonstrated that cultures of $\mathrm{T}$. harzianum grown in liquid media with a high carbon concentration and appropriate nitrogen and carbon sources differentiated to form MS and that these dried MS granules produced high concentrations of aerial conidia when rehydrated. Additionally, MS of T. harzianum were highly effective as a propagule type for introducing the antagonist into potting mix for the purpose of reducing dumping-off disease.

Efficacy studies revealed that the incorporation of $0.4 \mathrm{~g}$ dried MS granules of T. harzianum into potting soil enhanced emergence and reduced (>90\% suppression) damping-off disease incited by R. solani by increasing survival of melon plants (Table 4, Fig 4). While the mode of action of T. harzianum against $R$. solani-induced damping-off on melon seedlings was not the subject of this study, the ability of Trichoderma spp. to closely associate with the roots of numerous crop plants (Fig S2), enhance plant growth, and parasitize mycelium of pathogens could all play a role (Kubicek et al. 2001; Harman et al. 2004; Harman 2006; Verma et al. 2007).

Fungal biocontrol agents intended for use as biopesticides must survive drying and have extended shelf life at refrigerated and, preferably, room temperature. As an overwintering propagule, it is expected that MS of filamentous fungi would have the ability to survive longer than asexually produced conidia under natural conditions. Our data revealed that long-term storage of air-dried T. harzianum MS derived from different $\mathrm{C}: \mathrm{N}$ ratio media with a high carbon concentration exhibited excellent stability at $4{ }^{\circ} \mathrm{C}$ and room temperature $\left(25^{\circ} \mathrm{C}\right)$ with conidial production from MS harvested from nitrogen-rich medium (10:1 C:N ratio) being greatest (Table 3, Fig 1). Likewise, MS of Metarhizium spp. were also very stable in cool and unrefrigerated temperature storage when cultured in different liquid media (Jackson \& Jaronski 2012; Behle \& Jackson 2014; Mascarin et al. 2014). It is worth noting that MS of T. harzianum stored at $4{ }^{\circ} \mathrm{C}$ typically showed 


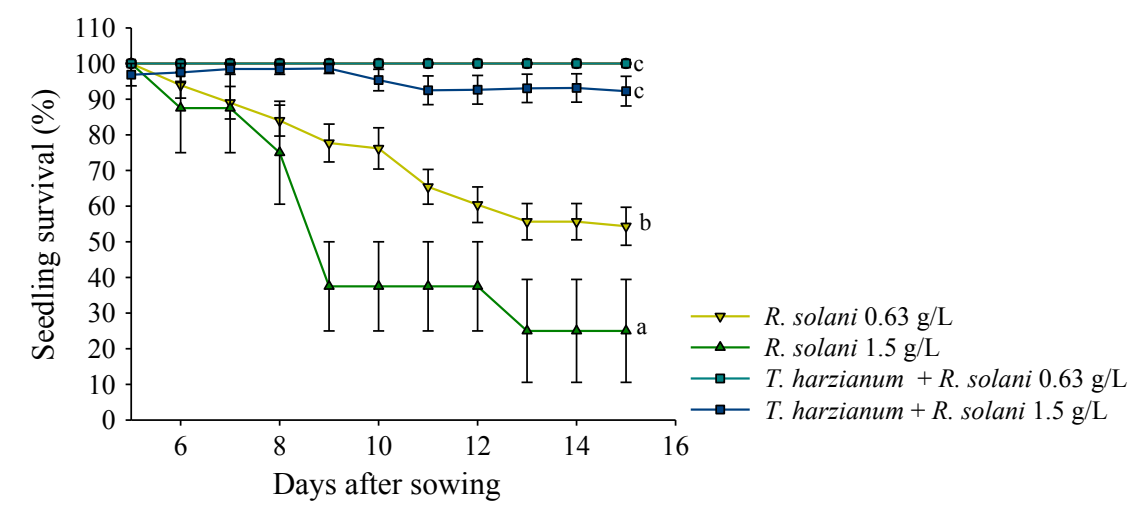

Fig 4 - Probability of emerged seedlings surviving post-emergence damping-off for Cantaloupe melon (cv. 'Hales Best') sown in soil infested by Rhizoctonia solani applied at two rates $\left(0.63\right.$ and $1.5 \mathrm{~g} \mathrm{~L}^{-1}$ potting $\left.\mathrm{mix}\right)$ with or without biological treatment

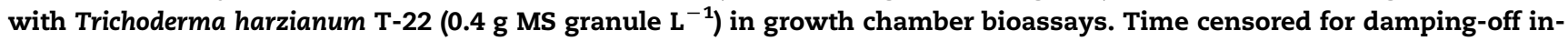
cidence up to $15 \mathrm{~d}$ after sowing. Values are means $( \pm \mathrm{SE})$ of three independent experiments. Survival curves followed by different letters are statistically significant according to the log-rank test $(P \leq 0.05)$.

a maturation process as conidial production dropped by month 3 and subsequently increased again in the following month. This phenomenon was also seen in MS of C. truncatum produced in liquid cultures (Jackson \& Schisler 1995), suggesting the possibility of MS undergoing a maturation process when kept in refrigeration.

The formation of MS by T. harzianum T-22 in liquid culture follows a developmental pattern similar to that seen in other fungi including C. truncatum (Jackson \& Schisler 1995), M. terrestris (Shearer \& Jackson 2006) and Metarhizium spp. (Jackson \& Jaronski 2009; Mascarin et al. 2014). Moreover, our recent studies have shown that many species of Trichoderma are capable of producing MS using liquid culture fermentation (data not shown). It is interesting to note that environmental and nutritional conditions, including aeration, $\mathrm{C}: \mathrm{N}$ ratio, nitrogen source, and culture age affected the melanization of MS of T. harzianum. Microsclerotia acquired a darker colour and were more melanized and compact as the culture aged when cottonseed flour was used as the nitrogen source (unpublished results). Sclerotial melanization also has been associated with prolonged persistence in soil and resistance to desiccation (stress tolerance) in various filamentous fungi (Coley-Smith \& Cooke 1971; Cooke 1983; Buttler \& Day 1998; Jackson \& Schisler 1995; Shearer \& Jackson 2006; Jackson \& Jaronski 2009). Therefore, this form of propagule would be more suitable than conidia for soil applications aiming at soilborne disease control. Studies are underway to determine the effects of melanization and MS size on desiccation tolerance, shelf life, and bioefficacy.

In our study, we also observed submerged conidia of $\mathrm{T}$. harzianum produced in nutritionally-poor media (Table 1). Nonetheless, these 7-day-old spores exhibited poor shelf life, which might be related to their lack of endogenous reserves. The endogenous reserves of fungal spores produced in liquid cultures have been associated with improved spore performance characteristics including desiccation tolerance, germination rate, and bioefficacy (Harman et al. 1991; Jin et al. 1991, 1996; Schisler et al. 1991). It is possible that the low survival rate during storage is related to the fact that submerged conidia of $\mathrm{T}$. harzianum were formed early (prior to day 4) in the $7 \mathrm{~d}$ fermentation period and thus they may have depleted endogenous reserves resulting in poor shelf life. Further studies are warranted to understand how culture age and endogenous reserves affect the desiccation tolerance and storage stability of submerged conidia. We also demonstrated that some liquid media were capable of producing acceptable yields of both submerged conidia and MS (Tables 1 and 2). Additional testing is required to determine if a product composed of both propagule types would have any applications that favour it over a product composed of a single propagule type.

Nitrogen is one of the most expensive components of the fermentation medium. We have shown that an inexpensive agricultural co-product high in nitrogen content such as cottonseed flour was suitable to produce high concentrations of T. harzianum MS in a short 4-day fermentation. The use of pre-culture inoculum based on 3-day-old submerged conidia of $\mathrm{T}$. harzianum increased biomass and MS production as well as reduced the fermentation time compared to cultures inoculated with aerial conidia harvested from PDA plates (Fig S1). Microsclerotia production and stabilization with low-cost nitrogen sources have been demonstrated for liquid fermentation of Metarhizium terrestris and Metarhizium brunneum with MS showing excellent biocontrol performance (Shearer \& Jackson 2006; Behle \& Jackson 2014). Microsclerotial granules of $\mathrm{T}$. harzianum produced in this low-cost liquid medium depicted quick germination $(<24 \mathrm{~h}$ ) with subsequent excellent conidial production (Table 3 ). The rapid sequence of MS granule germination and conidiation would enhance the ability of T. harzianum to quickly colonize plant tissues and rizhosphere to the detriment of plant pathogens.

In summary, we have demonstrated a novel liquid culture production process for desiccation tolerant MS of T. harzianum that are efficacious in reducing damping-off of melons. With additional advances in optimizing production and stabilization techniques for MS of T. harzianum, we expect that this 
and additional species of this biocontrol fungus will be more effectively stored and used in the integrated management of aerial and soilborne plant diseases.

\section{Competing interest}

The authors declare no competing interests.

\section{Acknowledgements}

The first author was recipient of a post-doctoral scholarship from CNPq - Brasil (Conselho Nacional de Desenvolvimento Científico e Tecnológico - Brazilian National Council for Scientific and Technological Development), and this work was partially sponsored by USDA.

\section{Appendix A. Supplementary data}

Supplementary data related to this article can be found at http://dx.doi.org/10.1016/j.funbio.2014.12.005.

\section{R E F E R E N C E S}

Bates DM, Maechler M, Bolker B, 2012. lme4: Linear mixed-effects models using S4 classes R package version 0.999999-0. Available at: http://cran.stat.sfu.ca/web/packages/lme4/lme4.pdf.

Behle RW, Jackson MA, 2014. Effect of fermentation media on the production, efficacy and storage stability of Metarhizium brunneum microsclerotia formulated as a prototype granule. Journal of Economic Entomology 107: 582-590.

Bettiol W, 2011. Biopesticides use and research in Brazil. Outlooks on Pest Management 280-283.

Buttler MJ, Day AW, 1998. Fungal melanins: a review. Canandian Journal of Microbiology 44: 1115-1136.

Coley-Smith JR, Cooke RC, 1971. Survival and germination of fungal sclerotia. Annual Review of Phytopathology 9: 65-92.

Cooke R, 1983. Morphogenesis of sclerotia. In: Smith JE (ed.), Fungal Differentiation: a contemporary synthesis. Marcel Dekker Inc, New York, NY, pp. 397-418.

Harman GE, Jin X, Stasz TE, Peruzzotti G, Leopold AC, Taylor AG, 1991. Production of conidial biomass of Trichoderma harzianum for biological control. Biological Control 1: 23-28.

Harman GE, 2000. Myths and dogmas of biocontrol: changes in perceptions derived from research on Trichoderma harzianum T-22. Plant Disease 84: 377-393.

Harman GE, 2006. Overview of mechanisms and uses of Trichoderma spp. Phytopathology 96: 190-194.

Harman GE, Howell CR, Viterbo A, Chet I, Lorito M, 2004. Trichoderma species - opportunistic, avirulent plant symbionts. Nature Reviews Microbiology 2: 43-56.

Harman GE, Kubicek PK, 1998. Trichoderma and Gliocladium. . In: Enzymes, Biological Control and Commercial Applications, vol. 2. Taylor and Francis, London1-393.

Harris AR, Schisler DA, Neate SM, 1993. Culture of Rhizoctonia solani and binucleate Rhizoctonia spp. on organic substrates for inoculation of seedlings in containers. Soil Biology and Biochemistry 25: 337-341.

Howell CR, 2003. Mechanisms employed by Trichoderma species in the biological control of plant diseases: the history and evolution of current concepts. Plant Disease 87: 4-10.
Jackson MA, Jaronski S, 2012. Development of pilot-scale fermentation and stabilization processes for the production of microsclerotia of the entomopathogenic fungus Metarhizium brunneun strain F52. Biocontrol Science and Technology 22: 915-930.

Jackson MA, Jaronski ST, 2009. Production of microsclerotia of the fungal entomopathogen Metarhizium anisopliae and their potential for use as a biocontrol agent for soil-inhabiting insects. Mycological Research 113: 842-850.

Jackson MA, McGuire MR, Lacey LA, Wraight SP, 1997. Liquid culture production of desiccation tolerant blastospores of the bioinsecticidal fungus Paecilomyces fumosoroseus. Mycological Research 101: 35-41.

Jackson MA, Schisler DA, 1992. The composition and attributes of Colletotrichum truncatum spores are altered by the nutritional environment. Applied and Environmental Microbiology 58: 2260-2265.

Jackson MA, Schisler DA, 1995. Liquid culture production of microsclerotia of Colletotrichum truncatum for use as bioherbicidal propagules. Mycological Research 99: 879-884.

Jin X, Harman GE, Taylor AG, 1991. Conidial biomass and desiccation tolerance of Trichoderma harzianum produced at different medium water potentials. Biological Control 1: 237-243.

Jin X, Taylor AG, Harman GE, 1996. Development of media and automated liquid fermentation methods to produce desiccation-tolerant propagules of Trichoderma harzianum. Biological Control 7: 267-274.

Jin X, Custis D, 2010. Microencapsulating aerial conidia of Trichoderma harzianum through spray drying at elevated temperatures. Biological Control 56: 202-208.

Kaplan EL, Meier P, 1958. Nonparametric estimation from incomplete observations. Journal of the American Statistical Association 53: 457-481.

Kubicek CP, Mach RL, Peterbauer CK, Lorito M, 2001. Trichoderma: from genes to biocontrol. Journal of Plant Pathology 83: 11-23.

Lewis JA, Papavizas GC, 1983. Production of chlamydospores and conidia by Trichoderma spp. in liquid and solid growth media. Soil Biology and Biochemistry 15: 351-357.

Lewis JA, Papavizas GC, 1985. Characteristics of alginate pellets formulated with Trichoderma and Gliocladium and their effect on the proliferation of the fungi in soil. Plant Pathology 34 : $571-577$.

Martin JP, 1950. Use of acid, rose-bengal and streptomycin in the plate method for estimating soil fungi. Soil Science 69: 215-232.

Mascarin GM, Kobori NN, de Jesus Vital RC, Jackson MA, Quintela ED, 2014. Production of microsclerotia by Brazilian strains of Metarhizium spp. using submerged liquid culture fermentation. World Journal of Microbiology and Biotechnology 30: 1583-1590.

Pandey A, Fernandes M, Larroche C, 2008. Current Developments in Solid-state Fermentation. Springer, New York, US 517. http: //dx.doi.org/10.1007/978-0-387-75213-6.

Papavizas GC, Dunn MT, Lewis JA, Beagle-Ristaino J, 1984. Liquid fermentation technology for experimental production of biocontrol fungi. Phytopathology 74: 1171-1175.

Pinheiro JC, Bates DM, 2000. Mixed-Effects Models in S and SPLUS. Springer, New York.

R Core Team, 2012. R: a language and environment for statistical computing. R Foundation for Statistical Computing, Vienna, Austria.

Ramanujam B, Prasad RD, Rangeswaran R, 2010. Mass production, formulation, quality control and delivery of Trichoderma for plant disease management. The Journal of Plant Protection Sciences 2: 1-8.

Ratkowsky D, 1990. Handbook of Nonlinear Regression Models. Marcel Dekker, New York and Basel. 
Schisler DA, Jackson MA, Bothast RJ, 1991. Influence of nutrition during conidiation of Colletotrichum truncatum on conidial germination and efficacy in inciting disease in Sesbania exaltata. Phytopathology 81: 587-590.

Schisler DA, Slininger PJ, 1994. Selection and performance of bacterial strains for biologically controlling Fusarium dry rot of potatoes incited by Gibberella pulicaris. Plant Disease 78: $251-255$.

Shearer JF, Jackson MA, 2006. Liquid culture production of microsclerotia of Mycoleptodiscus terrestris: a potential biological control agent for the management of hydrilla. Biological Control 38: 298-306.

Sriram S, Roopa KP, Savitha MJ, 2011. Extended shelf-life of liquid fermentation derived talc formulations of Trichoderma harzianum with the addition of glycerol in the production medium. Crop Protection 30: 1334-13339.

Tabachnik, M. Method of growing Trichoderma. Patent US 4837155 A; 1989.

Verma M, Brar SK, Tyagi RD, Surampalli RY, Val'ero JR, 2007. Antagonistic fungi, Trichoderma spp.: panoply of biological control. Biochemical Engineering Journal 37: 1-20.

Woo SL, Ruocco M, Vinale F, Nigro M, Marra R, Lombardi N, Pascale A, Lanzuise S, Manganiello G, Lorito, 2014. Trichoderma-based products and their widespread use in agriculture. The Open Mycology Journal 8: 71-126.

Yonsel, YS, Batum, MS. Trichoderma granule production. Patent EP20080866322; 2010. 